\title{
Detection of typical and atypical enteropathogenic Escherichia coli (EPEC) in Iranian children with and without diarrhoea
}

\begin{abstract}
Correspondence
M. Mehdi Aslani

mmaslani@yahoo.com or

mmaslani@pasteur.ac.ir
\end{abstract}

Received 24 January 2006

Accepted 22 May 2006
M. Yousef Alikhani, ${ }^{1,2}$ Akbar Mirsalehian ${ }^{1}$ and M. Mehdi Aslani ${ }^{3}$

\author{
${ }^{1}$ Department of Microbiology, Faculty of Medicine, Tehran University of Medical Sciences, \\ Tehran, Iran \\ ${ }^{2}$ Department of Microbiology, Faculty of Medicine, Hamadan University of Medical Sciences, \\ Hamadan, Iran \\ ${ }^{3}$ Department of Microbiology, Institute Pasteur of Iran, 69 Pasteur Avenue, Tehran, Iran
}

\begin{abstract}
The present study was performed to investigate the contribution of typical and atypical enteropathogenic Escherichia coli (EPEC) as a cause of infectious diarrhoea among children less than 10 years old in Iran. During the summer months, 247 specimens from children with diarrhoea and 1108 from asymptomatic children were analysed for the presence of EPEC and other bacterial pathogens. Potential enteric pathogens were identified in 140 cases of children with diarrhoea (56·7\%). EPEC was the most frequently identified agent (111 cases), followed by Shiga toxin-producing E. coli (13), Shigella (9), Salmonella (6) and Aeromonas sp. (1). EPEC isolates were examined for the presence of eaeA, bfp $A$ and stx genes by PCR. EPEC isolates were classified as typical $\left(e a e A^{+} b f p A^{+}\right.$) or atypical (eae $\left.A^{+} b f p A^{-}\right)$. Typical EPEC was diagnosed in 35 cases $(11.8 \%)$, compared with $8(0.4 \%)$ in the asymptomatic group $(P<0.05)$. Atypical EPEC strains were isolated from 23 cases $(9 \cdot 3 \%)$, compared with $13(1 \cdot 2 \%)$ of the healthy control group $(P<0.05)$. In conclusion, the data suggest that typical and atypical EPEC are an important cause of diarrhoea in Iranian children.
\end{abstract}

\section{INTRODUCTION}

Infectious diarrhoea is one of the world's leading causes of morbidity and mortality, resulting in about two million deaths per year (http://www.who.int). The majority of cases of serious diarrhoea occur among children in developing countries (World Health Organization, 1995). Enteropathogenic Escherichia coli (EPEC) is a major cause of infantile diarrhoea among children in developing countries (Levine, 1987; Donnenberg \& Kaper, 1992). The central mechanism of EPEC pathogenesis is a lesion called 'attaching and effacing' (A/E), which is characterized by intimate adherence of bacteria to the intestinal epithelium (Vallance \& Finlay, 2000). The eaeA gene, which is located in the 'locus of enterocyte effacement' pathogenicity island, and the $b f p A$ gene, located on a plasmid called the EPEC adherence factor (EAF), have both been used for identification of EPEC and for subdivision of this group of bacteria into typical and atypical strains (Nataro \& Kaper, 1998). E. coli strains with the A/E genotype $\left(e a e A^{+}\right)$that harbour the EAF plasmid $\left(b f p A^{+}\right)$are classified as 'typical EPEC' and strains with the $\mathrm{A} / \mathrm{E}$ genotype that do not posses the EAF

Abbreviations: $A / E$, attaching and effacing; EAF, EPEC adherence factor; EPEC, enteropathogenic Escherichia coli; STEC, Shiga toxinproducing E. coli. plasmid $\left(b f p A^{-}\right)$are classified as 'atypical EPEC' (Kaper, 1996). E. coli strains with and without the eaeA genotype that harbour Shiga toxin genes $\left(s t x_{1}\right.$ and/or $\left.s t x_{2}\right)$ are classified as Shiga toxin-producing E. coli (STEC) (Nataro \& Kaper, 1998). Typical EPEC is well recognized as a cause of gastroenteritis in infants (Nataro \& Kaper, 1998), whereas the role of atypical EPEC in childhood diarrhoea is still controversial. Most case-control studies have not been able to demonstrate any significant association between atypical EPEC and diarrhoea (Knutton et al., 2001; Scaletsky et al., 2002; Nunes et al., 2003; Afset et al., 2003, 2004; ReguaMangia et al., 2004). However, the majority of these studies have shown a higher prevalence of atypical EPEC among the group of subjects with diarrhoea than among the healthy controls, and it has been argued that atypical EPEC are probably pathogenic, as such strains are capable of colonizing the intestinal mucosa and produce A/E lesions (Knutton et al., 2001). There have also been reports of atypical EPEC being significantly associated with endemic diarrhoea (Vieira et al., 2001; Dulguer et al., 2003) or outbreaks (Yatsuyanagi et al., 2002; Jenkins et al., 2003). The aim of the present study was to investigate the relative contribution of typical and atypical EPEC among a randomly selected group of Iranian children with and without diarrhoea. 


\section{METHODS}

Subjects and strains. The strains examined in this study were isolated during the summer months in three Iranian provinces, Tehran, Ilam and Mazandaran. Random sampling was employed in two stages. In the first stage, the total population of the provinces was divided into 400-500 blocks, of which 50 were selected randomly. In the second stage, 8-15 families in each block were selected and a total of 1355 children under 10 years of age were chosen randomly for investigation for the presence of EPEC or other bacterial pathogens in their faeces.

Culture and identification methods. Samples were cultured for enteric pathogens by using standard methods (Murray et al., 2002). In brief, stool samples were cultured on Salmonella-Shigella agar and in Selenite F broth for Salmonella and Shigella spp., on two MacConkey agar plates for Yersinia spp. and on one Thiosulfate Citrate Bile Sucrose agar plate for Vibrio and Aeromonas spp. All plates were incubated at $37^{\circ} \mathrm{C}$ for $24-48 \mathrm{~h}$, except one MacConkey plate that was incubated at $25^{\circ} \mathrm{C}$. Presumptive colony identification was carried out according to Edwards and Ewing (Ewing, 1986). For both children with diarrhoea and healthy children, five colonies from the MacConkey plate were characterized for the detection of E. coli. Identification of $E$. coli was carried out by using standard biochemical methods (Forbes et al., 2002).

EPEC serogrouping. Strains biochemically identified as E. coli were selected and both lactose-positive and lactose-negative $E$. coli strains were serogrouped by using slide agglutination tests into the different EPEC serogroups (O26, O55, O86, O111, O114, O119, O124, O125, O126, O127, O128, O142) using O-specific antisera, according to the manufacturer's instructions (Bio-Rad). Strains that agglutinated with $4 \%$ saline were defined as rough.

Detection of virulence genes by PCR. EPEC isolates were examined by using PCR with the primers listed in Table 1 for the following virulence genes: eaeA (Beaudry et al., 1996), bfpA (Gunzburg et al., 1995) and stx (Lin et al., 1993). PCR was performed in a $25 \mu \mathrm{l}$ reaction mixture containing $100 \mu \mathrm{M}$ (each) dNTP, $1.5 \mathrm{mM} \mathrm{MgCl}_{2}$, $0.5 \mu \mathrm{M}$ (each) primer, $2.5 \mu \mathrm{l} 10$-fold-concentrated polymerase reaction buffer (Fermentas), $1 \mathrm{U}$ Taq polymerase (Fermentas) and $2 \mu \mathrm{l}$ template DNA. Primers and cycling conditions are listed in Table 1. Amplification reactions were performed in a thermal cycler (Eppendorf Mastercycler) and, for all amplification reactions, the mixture was heated at $94{ }^{\circ} \mathrm{C}$ for $5 \mathrm{~min}$ prior to thermocycling. The mixture was held at $72{ }^{\circ} \mathrm{C}$ for $7 \mathrm{~min}$ after the final cycle before cooling at $4{ }^{\circ} \mathrm{C}$. Amplified products were analysed by using $2 \%$ agarose gel electrophoresis and visualized by staining with ethidium bromide. A 100 bp DNA ladder (Fermentas) was used as a molecular size marker in all gels. Positive controls for PCR were E. coli strains

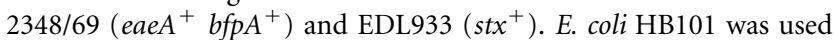
as a negative control.

Statistical analysis. $\chi^{2}$ test and Fisher's exact test were used for statistical analysis. Means \pm SD are given.

\section{RESULTS AND DISCUSSION}

\section{Subjects}

The 1355 stool specimens studied for the presence of EPEC were obtained from 247 children with diarrhoea $(0-10$ years old; mean age, $5 \cdot 5$ years) and 1108 children without any gastrointestinal symptoms ( $0-10$ years old; mean age, $6 \cdot 8$ years $)$.

\section{Potential enteropathogens other than EPEC}

A potential or established microbial pathogen was detected in $140(56 \cdot 7 \%)$ and $92(8 \cdot 3 \%)$ children with diarrhoea and asymptomatic controls, respectively. No mixed infections were observed. Shigella spp. were isolated from ten children, nine with diarrhoea and one without. Six Salmonella spp. were detected, all from diarrhoeal cases. Of the four Aeromonas spp. isolated, one was from a diarrhoeal case and the others were from asymptomatic children. STEC were isolated from 21 children, 13 with diarrhoea and 8 without. Vibrio cholerae and Yersinia spp. were not isolated in this study. No bacterial pathogens were isolated from the remaining 107 children with diarrhoea.

\section{Typical and atypical EPEC}

EPEC serogroups were isolated as the sole pathogen from $44.9 \%$ (111 of 247 ) of children with diarrhoea, compared with $7 \cdot 2 \%$ (80 of 1108 ) of those without diarrhoea $(P<0 \cdot 05)$. EPEC strains isolated in this study belonged to 11 EPEC serogroups (O26, O55, O86, O111, O114, O119, O125, O126, O127, O128 and O142). In children with diarrhoea, O111 serogroup EPEC (8.9\%) was the most prevalent, followed by O142 (8.5\%) and O127 (8\%). This is consistent with the findings of previous studies from

Table 1. Primer sequences, annealing temperatures and size of amplified products from selected genes of EPEC and STEC

$b f p A$, Bundle-forming pilus gene; eaeA, attaching and effacing-associated gene; STEC, Shiga toxin-producing E. coli; stx, Shiga toxin gene.

\begin{tabular}{|c|c|c|c|c|c|c|}
\hline Category & Target & Sequence $\left(5^{\prime}-3^{\prime}\right)$ & $\begin{array}{l}\text { Annealing temp. } \\
\qquad\left({ }^{\circ} \mathrm{C}\right)\end{array}$ & $\begin{array}{l}\text { No. of } \\
\text { cycles }\end{array}$ & $\begin{array}{l}\text { Fragment } \\
\text { size }(b p)\end{array}$ & Reference \\
\hline EPEC & eaeA & $\begin{array}{l}\text { F, CATTATGGAACGGCAGAGGT } \\
\text { R, ATCTTCTGCGTACTGCGTTCA }\end{array}$ & $55(1 \mathrm{~min})$ & 35 & 790 & Beaudry et al. (1996) \\
\hline EPEC & $b f p A$ & $\begin{array}{l}\text { F, AATGGTGCTTGCGCTTGCTGC } \\
\text { R, GCCGCTTTATCCAACCTGGTA }\end{array}$ & $60(1 \mathrm{~min})$ & 30 & 326 & Gunzburg et al. (1995) \\
\hline STEC & $s t x$ & $\begin{array}{l}\text { F, GAACGAAATAATTTATATGT } \\
\text { R, TTTGATTGTTACAGTCAT }\end{array}$ & $43(1.30 \mathrm{~min})$ & 39 & 900 & Lin et al. (1993) \\
\hline
\end{tabular}


Bangladesh (Albert et al., 1995), Saudi Arabia (El-Sheikh \& El-Assouli, 2001) and Uruguay (Torres et al., 2001). In children with diarrhoea, eight $(3 \cdot 2 \%)$ cases were colonized with two different ' $O$ ' serogroups of EPEC, whereas no healthy children were colonized with more than one ' $O$ ' serogroup of EPEC. In accordance with many studies in developing countries (Albert et al., 1995), a strong association of EPEC with diarrhoea was found. In other studies, children colonized with EPEC were rarely infected with other enteric pathogens (Echeverria et al., 1991; Gomes et al., 1991). A similar trend was found in the present study for the children infected with the EPEC serogroups. Surprisingly, EPEC was the most frequently identified potential pathogen in this study, identified in $44.9 \%$ of patients. This is a high prevalence compared with most other reports (Tompkins et al., 1999; Svenungsson et al., 2000; Keskimäki et al., 2001; Knutton et al., 2001; Vieira et al., 2001).
PCR was positive for the eaeA gene in 45 of $111(40 \cdot 5 \%)$ strains isolated from patients, compared with 16 of $80(20 \%)$ from children without diarrhoea (Table 2). The presence of the eaeA gene was also significantly more frequent (46\%) among strains belonging to serogroups O55 (9 of 14), O86 (12 of 23), O127 (11 of 33) and O114 (1 of 3) than among strains belonging to other serogroups. Interestingly, these serogroups are included among those that were isolated frequently from diarrhoeal cases. Case-control studies have found eaeA $A^{+}$E. coli strains more frequently in children with diarrhoea than in healthy controls in developing countries (Nataro \& Kaper, 1998; Rosa et al., 1998). Only 35 of 111 $(31.5 \%)$ strains isolated from children with diarrhoea and 8 of $80(10 \%)$ strains isolated from healthy controls gave positive results for the $b f p A$ gene (Table 2). In total, 45 of 247 $(18 \%)$ strains isolated from children with diarrhoea were negative for the two virulence markers (eaeA and $b f p A$ ) (nonEPEC). In this study, 29 of $111(26 \cdot 1 \%)$ and 5 of $80(6 \cdot 2 \%)$

Table 2. Genotypic characterization of typical, atypical and non-EPEC serogroups

\begin{tabular}{|c|c|c|c|c|c|}
\hline Serogroup & No. of strains & \multicolumn{2}{|c|}{ Clinical sign } & PCR result & Virulence category \\
\hline O111 & 5 & 0 & 5 & $e a e A^{+} b f p A^{+} s t x^{-}$ & Typical EPEC \\
\hline O111 & 12 & 5 & 7 & $e a e A^{+} b f p A^{-} s t x^{-}$ & Atypical EPEC \\
\hline O111 & 1 & 0 & 1 & $e a e A^{-}$bfp $A^{+} s t x^{-}$ & Atypical EPEC \\
\hline O111 & 2 & 1 & 1 & $e a e A^{-} b f p A^{-} s t x^{+}$ & STEC \\
\hline $\mathrm{O} 127$ & 7 & 5 & 2 & $e a e A^{+} b f p A^{-} s t x^{-}$ & Atypical EPEC \\
\hline $\mathrm{O} 127$ & 1 & 1 & 0 & $e a e A^{-} b f p A^{+} s t x^{-}$ & Atypical EPEC \\
\hline O127 & 1 & 1 & 0 & $e a e A^{-}$bfp $A^{-} s t x^{+}$ & STEC \\
\hline O127 & 20 & 9 & 11 & $e a e A^{-} \quad b f p A^{-} s t x^{-}$ & Non-EPEC \\
\hline $\mathrm{O} 142$ & 4 & 4 & 0 & $e a e A^{+}$bfp $A^{+} s t x^{-}$ & Typical EPEC \\
\hline O86 & 2 & 2 & 0 & $e a e A^{+} b f p A^{-} s t x^{-}$ & Atypical EPEC \\
\hline O86 & 1 & 1 & 0 & $e a e A^{-}$bfp $A^{+} s t x^{-}$ & Atypical EPEC \\
\hline O86 & 10 & 4 & 6 & $e a e A^{-} \quad b f p A^{-} s t x^{-}$ & Non-EPEC \\
\hline $\mathrm{O} 26$ & 1 & 1 & 0 & $e a e A^{+} \quad b f p A^{+} s t x^{-}$ & Typical EPEC \\
\hline $\mathrm{O} 26$ & 1 & 1 & 0 & $e a e A^{-}$bfp $A^{-} s t x^{+}$ & STEC \\
\hline $\mathrm{O} 26$ & 4 & 2 & 2 & $e a e A^{-} \quad b f p A^{-} s t x^{-}$ & Non-EPEC \\
\hline O55 & 9 & 9 & 0 & $e a e A^{+} b f p A^{+} s t x^{-}$ & Typical EPEC \\
\hline O55 & 5 & 1 & 4 & $e a e A^{-} \quad b f p A^{-} s t x^{-}$ & Non-EPEC \\
\hline O119 & 1 & 1 & 0 & $e a e A^{+} b f p A^{+} s t x^{-}$ & Typical EPEC \\
\hline O119 & 7 & 3 & 4 & $e a e A^{-} b f p A^{-} s t x^{-}$ & Non-EPEC \\
\hline
\end{tabular}


EPEC strains isolated from cases and healthy controls, respectively, were typical EPEC $\left(e a e A^{+} b f p A^{+}\right)$. Typical EPEC was much more prevalent in cases with diarrhoea $(11 \cdot 8 \%)$ than in healthy children $(0 \cdot 4 \%)(P<0 \cdot 05)$. This shows that the typical EPEC strains continue to be an important cause of diarrhoea in children. These strains were isolated from patients with acute or persistent diarrhoea (Scaletsky et al., 1999). In this report, typical EPEC strains were mostly encountered among the strains belonging to serogroups O55 and O86 (Table 2), which differs from the findings of a previous study in Iran (Bouzari et al., 2000).

In 23 of $111(20 \cdot 7 \%)$ and 13 of $80(16 \cdot 2 \%)$ EPEC strains isolated from cases and healthy controls, respectively, only one of these determinants (eaeA, $b f p A$ ) was found (atypical EPEC). Most atypical EPEC isolates $(72 \cdot 2 \%)$ constituted the eaeA-positive isolates. This finding is in accordance with recent reports from the UK (Knutton et al., 2001) and Brazil (Dulguer et al., 2003). Atypical EPEC strains were mostly encountered among strains belonging to serogroups O114 and $\mathrm{O} 142$ (Table 2), which is different from another report (Gonçalves et al., 1997). Atypical EPEC strains were isolated from cases with diarrhoea $(9 \cdot 3 \%)$ and healthy controls $(1 \cdot 2 \%)(P<0 \cdot 05)$. Atypical EPEC has been implicated as the causative agent in some outbreaks (Scotland et al., 1993; Viljanen et al., 1990), whereas in other studies atypical EPEC has not been recovered more frequently from diarrhoeal cases than from controls (Echeverria et al., 1991). In some studies, the rate of isolation of atypical EPEC from children without diarrhoea was twice that of cases with diarrhoea (Gomes et al., 2002; Dulguer et al., 2003). There have also been reports of atypical EPEC associated with both endemic diarrhoea (Bokete et al., 1997; Vieira et al., 2001) and outbreaks (Hedberg et al., 1997; Yatsuyanagi et al., 2002). Nevertheless, the role of atypical EPEC in diarrhoea has not been established conclusively. Although in our study the association of atypical EPEC with diarrhoea was statistically significant, to elucidate the role of atypical EPEC in diarrhoeal disease among Iranian children, more epidemiological studies and further investigation of the virulence properties of these strains are warranted.

\section{Conclusions}

We conclude that EPEC strains that possess the eaeA gene are a common cause of diarrhoea in Iranian children. Typical EPEC was more prevalent in children with diarrhoea $(11.8 \%)$ than in healthy cases $(0.4 \%)$. Atypical EPEC is prevalent among children with diarrhoea in Iran and was diagnosed in $9 \cdot 3 \%$ of patients in this study. Detection of the $e a e A$ and $b f p A$ genes is a useful method for the identification of and differentiation between typical and atypical EPEC strains.

\section{ACKNOWLEDGEMENTS}

We are grateful to Dr S. Bouzari and Dr H. Shojaei for critical discussion. We are also indebted to Mr S. Andalibi for help in statistical analysis. Miss F. Shoraj, Miss M. Parzadeh, Mr J. Raeisi, Mr H. Khamse and $\mathrm{Mr} \mathrm{H}$. Shafie are acknowledged for their technical help and we would like to thank the authority and personnel of the Health Departments of Tehran, Ilam and Mazandaran provinces.

\section{REFERENCES}

Afset, J. E., Bergh, K. \& Bevanger, L. (2003). High prevalence of atypical enteropathogenic Escherichia coli (EPEC) in Norwegian children with diarrhoea. J Med Microbiol 52, 1015-1019.

Afset, J. E., Bevanger, L., Romundstad, P. \& Bergh, K. (2004). Association of atypical enteropathogenic Escherichia coli (EPEC) with prolonged diarrhoea. J Med Microbiol 53, 1137-1144.

Albert, M. J., Faruque, S. M., Faruque, A. S. G., Neogi, P. K. B., Ansaruzzaman, M., Bhuiyan, N. A., Alam, K. \& Akbar, M. S. (1995). Controlled study of Escherichia coli diarrheal infections in Bangladeshi children. J Clin Microbiol 33, 973-977.

Beaudry, M., Zhu, C., Fairbrother, J. M. \& Harel, J. (1996). Genotypic and phenotypic characterization of Escherichia coli isolates from dogs manifesting attaching and effacing lesions. J Clin Microbiol 34, 144-148.

Bokete, T. N., Whittam, T. S., Wilson, R. A., Clausen, C. R., O'Callahan, C. M., Moseley, S. L., Fritsche, T. R. \& Tarr, P. I. (1997). Genetic and phenotypic analysis of Escherichia coli with enteropathogenic characteristics isolated from Seattle children. J Infect Dis 175, 1382-1389.

Bouzari, S., Jafari, M. N., Shokouhi, F., Parsi, M. \& Jafari, A. (2000). Virulence-related DNA sequences and adherence patterns in strains of enteropathogenic Escherichia coli. FEMS Microbiol Lett 185, 89-93.

Donnenberg, M. S. \& Kaper, J. B. (1992). Enteropathogenic Escherichia coli. Infect Immun 60, 3953-3961.

Dulguer, M. V., Fabbricotti, S. H., Bando, S. Y., Moreira-Filho, C. A., Fagundes-Neto, U. \& Scaletsky, I. C. (2003). Atypical enteropathogenic Escherichia coli strains: phenotypic and genetic profiling reveals a strong association between enteroaggregative $E$. coli heatstable enterotoxin and diarrhea. J Infect Dis 188, 1685-1694.

Echeverria, P., Orskov, F., Orskov, I., Knutton, S., Scheutz, F., Brown, J. E. \& Lexomboon, U. (1991). Attaching and effacing enteropathogenic Escherichia coli as a cause of infantile diarrhea in Bangkok. J Infect Dis 164, 550-554.

El-Sheikh, S. M. \& El-Assouli, S. M. (2001). Prevalence of viral, bacterial and parasitic enteropathogens among young children with acute diarrhoea in Jeddah, Saudi Arabia. J Health Popul Nutr 19, 25-30.

Ewing, W. H. (1986). Edward and Ewing's Identification of Enterobacteriaceae, 4th edn. New York: Elsevier.

Forbes, B. E., Sahm, D. F., Weissfeld, A. S. \& Trevino, E. A. (2002). Bailey \& Scott's Diagnostic Microbiology, 11th edn. Toronto: The C.V. Mosby Company.

Gomes, T. A. T., Rassi, V., MacDonald, K. L. \& 8 other authors (1991). Enteropathogens associated with acute diarrheal disease in urban infants in Sao Paulo, Brazil. J Infect Dis 164, 331-337.

Gomes, T. A. T., Irino, K. \& other authors (2002). Escherichia coli $e a e^{+} \mathrm{EAF}^{-}$stx $^{-}$strains outside the EPEC serogroups. In Abstracts of the 3rd International EPEC Symposium, abstract no. S1.5. Puerto Vallarta, Mexico.

Gonçalves, A. G., Campos, L. C., Gomes, T. A. T., Rodrigues, J., Sperandio, V., Whittam, T. S. \& Trabulsi, L. R. (1997). Virulence properties and clonal structures of strains of Escherichia coli O119 serotypes. Infect Immun 65, 2034-2040. 
Gunzburg, S. T., Tornieporth, N. G. \& Riley, L. W. (1995). Identification of enteropathogenic Escherichia coli by PCR-based detection of the bundle-forming pilus gene. J Clin Microbiol 33, 1375-1377.

Hedberg, C. W., Savarino, S. J., Besser, J. M. \& 7 other authors (1997). An outbreak of foodborne illness caused by Escherichia coli O39: NM, an agent not fitting into the existing scheme for classifying diarrheogenic E. coli. J Infect Dis 176, 1625-1628.

Jenkins, C., Lawson, A. J., Cheasty, T., Willshaw, G. A., Wright, P., Dougan, G., Frankel, G. \& Smith, H. R. (2003). Subtyping intimin genes from enteropathogenic Escherichia coli associated with outbreaks and sporadic cases in the United Kingdom and Eire. Mol Cell Probes 17, 149-156.

Kaper, J. B. (1996). Defining EPEC. Rev Microbiol 27, 130-133.

Keskimäki, M., Eklund, M., Pesonen, H., Heiskanen, T. \& Siitonen, A. (2001). EPEC, EAEC and STEC in stool specimens: prevalence and molecular epidemiology of isolates. The Study Group. Diagn Microbiol Infect Dis 40, 151-156.

Knutton, S., Shaw, R., Phillips, A. D., Smith, H. R., Willshaw, G. A., Watson, P. \& Price, E. (2001). Phenotypic and genetic analysis of diarrhea-associated Escherichia coli isolated from children in the United Kingdom. J Pediatr Gastroenterol Nutr 33, 32-40.

Levine, M. M. (1987). Escherichia coli that cause diarrhea: enterotoxigenic, enteropathogenic, enteroinvasive, enterohemorrhagic, and enteroadherent. J Infect Dis 155, 377-389.

Lin, Z., Kurazono, H., Yamasaki, S. \& Takeda, Y. (1993). Detection of various variant verotoxin genes in Escherichia coli by polymerase chain reaction. Microbiol Immunol 37, 543-548.

Murray, P. R., Baron, E. J., Pfaller, M. A., Tenover, F. C. \& Yolken, R. H. (2002). Manual of Clinical Microbiology, 7th edn. Washington, DC: American Society for Microbiology.

Nataro, J. P. \& Kaper, J. B. (1998). Diarrheagenic Escherichia coli. Clin Microbiol Rev 11, 142-201.

Nunes, E. B., Saridakis, H. O., Irino, K. \& Pelayo, J. S. (2003). Genotypic and phenotypic characterization of attaching and effacing Escherichia coli (AEEC) isolated from children with and without diarrhoea in Londrina, Brazil. J Med Microbiol 52, 499-504.

Regua-Mangia, A. H., Gomes, T. A., Vieira, M. A., Andrade, J. R., Irino, K. \& Teixeira, L. M. (2004). Frequency and characteristics of diarrhoeagenic Escherichia coli strains isolated from children with and without diarrhoea in Rio de Janeiro, Brazil. J Infect 48, 161-167.

Rosa, A. C., Mariano, A. T., Pereira, A. M., Tibana, A., Gomes, T. A. \& Andrade, J. R. (1998). Enteropathogenicity markers in Escherichia coli isolated from infants with acute diarrhoea and healthy controls in Rio de Janeiro, Brazil. J Med Microbiol 47, 781-790.
Scaletsky, I. C. A., Pedroso, M. Z., Oliva, C. A., Carvalho, R. L. B., Morais, M. B. \& Fagundes-Neto, U. (1999). A localized adherencelike pattern as a second pattern of adherence of classic enteropathogenic Escherichia coli to HEp-2 cells that is associated with infantile diarrhea. Infect Immun 67, 3410-3415.

Scaletsky, I. C. A., Fabbricotti, S. H., Aranda, K. R., Morais, M. B. \& Fagundes-Neto, U. (2002). Comparison of DNA hybridization and PCR assays for detection of putative pathogenic enteroadherent Escherichia coli. J Clin Microbiol 40, 1254-1258.

Scotland, S. M., Willshaw, G. A., Smith, H. R., Said, B., Stokes, N. \& Rowe, B. (1993). Virulence properties of Escherichia coli strains belonging to serogroups $\mathrm{O} 26, \mathrm{O} 55, \mathrm{O} 111$ and $\mathrm{O} 128$ isolated in the United Kingdom in 1991 from patients with diarrhoea. Epidemiol Infect 111, 429-438.

Svenungsson, B., Lagergren, A., Ekwall, E., Evengard, B., Hedlund, K. O., Karnell, A., Lofdahl, S., Svensson, L. \& Weintraub, A. (2000). Enteropathogens in adult patients with diarrhea and healthy control subjects: a 1-year prospective study in a Swedish clinic for infectious diseases. Clin Infect Dis 30, 770-778.

Tompkins, D. S., Hudson, M. J., Smith, H. R. \& 8 other authors (1999). A study of infectious intestinal disease in England: microbiological findings in cases and controls. Commun Dis Public Health 2, 108-113.

Torres, M. E., Pirez, M. C., Schelotto, F. \& 13 other authors (2001). Etiology of childern's diarrhea in Montevideo, Uruguay: associated pathogens and unusual isolates. J Clin Microbiol 39, 2134-2139.

Vallance, B. A. \& Finlay, B. B. (2000). Exploitation of host cells by enteropathogenic Escherichia coli. Proc Natl Acad Sci U S A 97, 8799-8806.

Vieira, M. A. M., Andrade, J. R. C., Trabulsi, L. R., Rosa, A. C. P., Dias, A. M. G., Ramos, S. R. T. S., Frankel, G. \& Gomes, T. A. T. (2001). Phenotypic and genotypic characteristics of Escherichia coli strains of non-enteropathogenic E. coli (EPEC) serogroups that carry eae and lack the EPEC adherence factor and Shiga toxin DNA probe sequences. J Infect Dis 183, 762-772.

Viljanen, M. K., Peltola, T., Junnila, S. Y. T., Olkkonen, L., Jarvinen, H., Kuistila, M. \& Huovinen, P. (1990). Outbreak of diarrhoea due to Escherichia coli O111:B4 in school children and adults: association of $\mathrm{Vi}$ antigen-like reactivity. Lancet 336, 831-834.

World Health Organization (1995). Bridging the Gaps. The World Health Report. http://www.who.int/whr2001/2001/archives/1995/index. htm

Yatsuyanagi, J., Saito, S., Sato, H., Miyajima, Y., Amano, K. \& Enomoto, K. (2002). Characterization of enteropathogenic and enteroaggregative Escherichia coli isolated from diarrheal outbreaks. J Clin Microbiol 40, 294-297. 